\title{
KEANEKARAGAMAN JENIS BURUNG PADA BERBAGAI TIPE PEMANFAATAN LAHAN DI KAWASAN MUARA KALI LAMONG, PERBATASAN SURABAYA - GRESIK
}

\author{
Hening Swastikaningrum*, Sucipto Hariyanto, Bambang Irawan \\ Departemen Biologi, Fakultas Sains dan Teknologi Universitas Airlangga \\ Kampus C UNAIR, Jl. Mulyorejo, Surabaya 60115 \\ *E-mail: swastikaningrum@gmail.com
}

\begin{abstract}
The object of this study was to determined the bird species diversity around the estuary region of Kali Lamong located in between Surabaya and Gresik, East Java. Observation was taken three kilometers far, started from Galang Island in Kali Lamong estuary to upstream side of the river. Twelve stations were made along the river as representative type of five land use. Station I and IV represented settlement area. Station II, III, and VIII represented industrial sites, station V and VI represented lawn, and station VII, IX, and X represented aquaculture. Each stations had 20 meter (bulls eye diameter) range or equivalent with $1.256 \mathrm{~m}^{2}$. Every bird in the area was recorded and analyzed by Shannon- Wiener diverity index. The results of this study shown aquaculture area has the highest diversity index (3,19). Followed by lawn (2,52), industrial site (2,39), mangrove forest $(2,06)$, and settlement area $(1,67)$.
\end{abstract}

Keywords: Bird species diversity, Kali Lamong, Land use, Species abundance, Similarity index

\section{PENGANTAR}

Pantura atau Pantai Utara Pulau Jawa yang merupakan bagian dari kawasan pesisir, telah menjadi pusat berbagai kegiatan manusia sejak jaman kerajaan mendominasi di Indonesia. Seiring berjalannya waktu, wilayah-wilayah di sekitar Pantura tumbuh menjadi kota-kota besar yang dinamis dan seolah tidak pernah berhenti membangun. Dua dari beberapa kota yang tengah berkembang di kawasan Pantura adalah Surabaya dan Gresik. Di antara kota ini terletak sebuah sungai yang merupakan bagian dari DAS Bengawan Solo yaitu Kali Lamong (Sulistyaningsih, 2009).

Kali Lamong merupakan sungai yang dekat dengan wilayah muara dan berpusat di Teluk Lamong, Jawa Timur. Sejak awal tahun 1980-an, di sepanjang Kali Lamong terdapat kurang lebih 1.300 bangunan dan 17 unit industri yang berpotensi mengancam ekosistem di sekitar Kali Lamong (Bapeprov Jatim, 2010).

Hal yang mengancam ekosistem tersebut juga ditambah dengan rencana pembangunan Lamong Bay untuk terminal peti kemas, perluasan Tanjung Perak, dan proyek Waterfront City. Bila rencana-rencana tersebut terealisasi, maka akan terjadi peningkatan potensi konsentrasi limbah, perusakan kawasan mangrove di sepanjang sungai hingga pesisir, dan percepatan laju sedimentasi sungai Kali Lamong (Bapeprov Jatim, 2010).

Realisasi tersebut juga berarti perusakan pada lingkup habitat makhluk hidup. Padahal, perusakan habitat dan eksploitasi sumber daya alam secara berlebihan telah menyebabkan Indonesia memiliki daftar spesies fauna terancam punah terpanjang di dunia, mencakup 126 spesies burung, 63 spesies mamalia, dan 21 spesies reptil (Sumardja, 1998 dalam Widodo, 2009).

Secara khusus, saat ini terdapat 1.111 jenis burung (11\%) di dunia yang secara global terancam punah. Ditambah dengan 11 jenis $(0,1 \%)$ dikategorikan dalam status Tergantung Aksi Konservasi, 66 jenis (1\%) Kurang Data, dan 877 jenis (9\%) Mendekati Terancam Punah. Dengan kata lain, lebih dari seperlima dari semua jenis burung yang ada di dunia perlu untuk mendapat perhatian. Keterancaman tersebut diakibatkan oleh menurunnya kualitas lingkungan dan hilangnya habitat (Shahnaz dkk., 1995).

Penelitian ini melaporkan hasil pengamatan terhadap keanekaragaman jenis burung pada berbagai tipe pemanfaatan lahan di sekitar kawasan muara Kali Lamong. Asumsi yang digunakan adalah apabila terdapat perbedaan tipe pemanfaatan lahan, maka akan dijumpai pula perbedaan keanekaragaman jenis burung.

\section{BAHAN DAN CARA KERJA}

\section{Tempat dan Waktu Penelitian}

Penelitian dilakukan di sekitar kawasan muara Kali Lamong, perbatasan Surabaya-Gresik. Tahapan penelitian pendahuluan dilakukan pada bulan Oktober-November 
2011, sedang penelitian lanjutan dilakukan sepanjang Bulan Februari-Mei 2012.

\section{Alat Penelitian}

Alat yang digunakan selama penelitian adalah meteran, anemometer, sling psychrometric, hand refracto salinometer, GPS, binokular Canon $8 \times 25$, monokular, buku panduan pengamatan Burung-Burung di Sumatera, Jawa, Bali, dan Kalimantan (MacKinnon et al., 2010) dan Waterbird of Asia (Bhushan et al., 1993), catatan dan alat tulis, jam tangan, hand counter, dan Kamera DSLR Canon 550D dengan Canon tele lens 75-300 mm.

\section{Cara Kerja}

\section{Penentuan lokasi stasiun}

Stasiun penelitian ditentukan melalui pengamatan pendahuluan berdasarkan perbedaan fungsi lahan yang tampak dalam citra satelit udara oleh aplikasi Google Earth lalu dilanjutkan dengan observasi langsung ke lokasi penelitian. Ditentukan 12 koordinat stasiun hasil penandaan dengan GPS seperti disajikan Tabel 1. Sedang peta lokasi pengamatan dapat dilihat pada Gambar 1.

Tabel 1. Koordinat Stasiun Pengamatan Burung di Muara Kali Lamong

\begin{tabular}{|c|c|c|}
\hline Stasiun & Koordinat & Pemanfaatan Lahan \\
\hline $\mathrm{I}$ & $\begin{array}{l}\text { S 07011. 38,3" } \\
\text { E112 } 12^{\circ} 3.11,01^{\prime \prime}\end{array}$ & Permukiman \\
\hline II & $\begin{array}{l}\text { S } 07^{\circ} 11.69,0^{\prime \prime} \\
\text { E } 112^{\circ} 38.70,5^{\prime \prime}\end{array}$ & Perindustrian \\
\hline III & $\begin{array}{l}\text { S } 07^{\circ} 11.58,4^{\prime \prime} \\
\text { E } 112^{\circ} 38.47,3^{\prime \prime}\end{array}$ & Perindustrian \\
\hline IV & $\begin{array}{l}\text { S } 07^{\circ} 11.69,0^{\prime \prime} \\
\text { E } 112^{\circ} 38.70,5^{\prime \prime}\end{array}$ & Permukiman \\
\hline V & $\begin{array}{l}\text { S } 07^{\circ} 11.63,5^{\prime \prime} \\
\text { E } 112^{\circ} 38.75,5^{\prime \prime}\end{array}$ & Lahan Kosong \\
\hline VI & $\begin{array}{l}\text { S } 07^{\circ} 11.72,2^{\prime \prime} \\
\text { E } 112^{\circ} 38.76,1^{\prime \prime}\end{array}$ & Lahan Kosong \\
\hline VII & $\begin{array}{l}\text { S } 07^{\circ} 11.67,6^{\prime \prime} \\
\text { E } 112^{\circ} 39.14,7^{\prime \prime}\end{array}$ & Pertambakan \\
\hline VIII & $\begin{array}{l}\text { S } 07^{\circ} 11.63,5^{\prime \prime} \\
\text { E } 112^{\circ} 38.75,5^{\prime \prime}\end{array}$ & Perindustrian \\
\hline IX & $\begin{array}{l}\text { S } 07^{\circ} 11.64,1^{\prime \prime} \\
\text { E } 112^{\circ} 39.48,7^{\prime \prime}\end{array}$ & Pertambakan \\
\hline $\mathrm{X}$ & $\begin{array}{l}\text { S } 07^{\circ} 11.80,4^{\prime \prime} \\
\text { E } 112^{\circ} 39.82,5^{\prime \prime}\end{array}$ & Pertambakan \\
\hline$X I$ & $\begin{array}{l}\text { S } 07^{\circ} 11.76,1^{\prime \prime} \\
\text { E } 112^{\circ} 39.85,7^{\prime \prime}\end{array}$ & Hutan Mangrove \\
\hline XII & $\begin{array}{l}\text { S } 07^{\circ} 11.83,2^{\prime \prime} \\
\text { E } 112^{\circ} 40.00,4^{\prime \prime}\end{array}$ & Hutan Mangrove \\
\hline
\end{tabular}

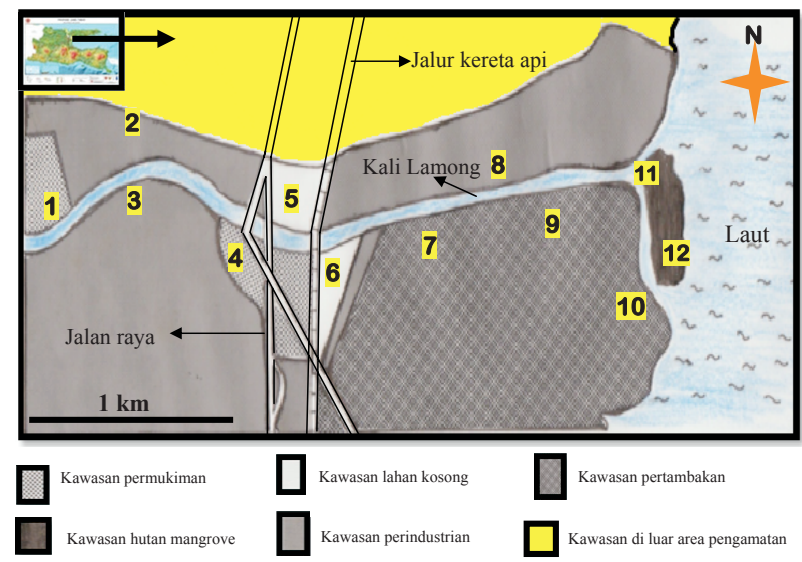

Gambar 1. Denah Lokasi Penelitian (Nomor dalam gambar menunjukkan stasiun)

\section{Inventarisasi jenis burung}

Kegiatan ini bertujuan untuk mencatat jenis burung yang terdapat di masing-masing stasiun. Kemudian dihitung indeks keanekaragamannya menggunakan formula Shannon-Wiener. Soegianto (1994) menyatakan, jika data kelimpahan jenis diambil secara acak dari suatu komunitas atau subkomunitas, maka penghitungan keanekaragaman jenis yang tepat adalah dengan menggunakan indeks keanekaragaman Shannon (Shannon-Wiener).

$\mathrm{H}^{\prime}=-\sum\left(\mathrm{p}_{\mathrm{i} .} \ln \mathrm{p}_{\mathrm{i}}\right)$

$\mathrm{H}^{\prime}=$ indeks keanekaragaman Shannon,

$\mathrm{p}_{\mathrm{i}}=\mathrm{n}_{\mathrm{i}} / \mathrm{N}$, perbandingan antara jumlah individu spesies ke- ${ }_{i}$ dengan jumlah total individu,

$\mathrm{n}_{\mathrm{i}}=$ jumlah suatu jenis,

$\mathrm{N}=$ jumlah seluruh jenis yang ada dalam contoh.

Tingkat keanekaragaman diklasifikasikan berdasarkan kriteria Lee et al., (1978) dalam Arisandi (1999), yaitu: Sangat Tinggi $\mathrm{H}>3,0$; Tinggi jika $\mathrm{H}>2,0$; Sedang jika $1,6<\mathrm{H}<2,0$; Rendah jika $1,0<\mathrm{H}<1,5$; Sangat rendah jika $\mathrm{H}<1,0$.

\section{Pengukuran parameter fisik lingkungan}

Pada stasiun dicatat faktor fisik yang meliputi: lebar dan panjang sungai, temperatur udara, kelembapan udara, salinitas air, kecepatan angin, pasang surut air laut, dan kondisi astronomis. Pengukuran panjang dan lebar sungai menggunakan citra satelit Google Earth. Semua parameter fisik ini digunakan sebagai data penunjang.

\section{Prosedur pengamatan}

Identifikasi jenis burung menggunakan metode point count berdasarkan Carlton (2004) dan Hostetler dan Main 
(2011) dengan berjalan kaki dan naik perahu. Identifikasi burung dilakukan berdasar ciri morfologi (bentuk dan warna tubuh, paruh, kaki, dan bulu) burung yang diamati.

\section{HASIL}

\section{Deskripsi lahan pengamatan}

Dari hasil penandaan stasiun didapatkan lima tipe pemanfaatan lahan di sekitar muara sungai seperti pada Gambar 2, yaitu berupa kawasan permukiman, perindustrian, lahan kosong, pertambakan, dan hutan mangrove. Stasiun I merupakan kawasan permukiman yang berbatasan dengan Kali Lamong di sisi selatan. Stasiun ini masuk ke dalam wilayah Gresik, tepatnya Desa Segoromadu, Kecamatan Kebomas. Sepanjang bantaran sungai, berjajar perahu dan berdiri kompleks perkampungan nelayan dengan aktivitas penduduk yang padat.

Stasiun II masuk ke dalam wilayah Gresik, diapit oleh perindustrian di sisi utara dan Kali Lamong di sisi selatan. Stasiun ini berdekatan dengan jalan raya, sehingga membuat keadaan stasiun ini ramai dan minim vegetasi. Keadaan ini serupa dengan Stasiun III yang merupakan bagian dari kawasan industri dan termasuk dalam wilayah Surabaya. Aktivitas industri dan arus transportasi di sini tidak kalah padat dengan stasiun II.

Stasiun IV merupakan kawasan permukiman yang berbatasan dengan Kali Lamong di sisi utaranya. Stasiun ini juga berdekatan dengan jalur jembatan jalan raya penghubung Surabaya dan Gresik dan masuk dalam wilayah Surabaya. Stasiun V adalah kawasan lahan kosong yang masuk dalam wilayah Gresik dengan sisi selatan stasiun ini berbatasan dengan Kali Lamong, sementara sisi barat berbatasan dengan jalan raya penghubung Surabaya-Gresik. Salah satu titik pada sisi utara lahan kosong ini tengah mengalami proses pengurukan tanah untuk mendukung sebuah proyek industri.

Stasiun VI merupakan kawasan lahan kosong yang berada di sisi Kali Lamong wilayah Surabaya. Wilayah ini diapit oleh permukiman, jalan raya Osowilangon, dan area industri.

Stasiun VII merupakan salah satu stasiun yang mewakili area pertambakan dan masuk dalam wilayah Surabaya. Jenis tambak di stasiun ini adalah tambak ikan dan garam dengan vegetasi mangrove jenis Rhizopora sp. dan Avicennia sp. yang rapat di sekitar tambak.

Stasiun VIII adalah perwakilan dari daerah industri sektor logging yang masuk ke dalam kawasan Gresik. Stasiun IX merupakan kawasan pertambakan yang termasuk ke dalam wilayah Surabaya dan bertipe tambak serupa dengan stasiun VII. Stasiun X juga merupakan stasiun berupa lokasi pertambakan. Bertempat tepat di seberangan Pulau Galang di bagian timur dan bersebelahan dengan Tempat Pelelangan Ikan di bagian selatan stasiun.

Stasiun XI dan XII berlokasi di Pulau Galang yang menjadi perwakilan area hutan mangrove. Stasiun XI berada di sisi timur Pulau Galang dan berhadapan langsung dengan Teluk Lamong.

Pada stasiun XII, khususnya saat surut, akan nampak dataran lumpur (gosongan) yang berlaku sebagai feeding ground, terutama bagi burung-burung air.

\section{Keanekaragaman burung}

Hasil inventarisasi selama sembilan kali pengamatan dalam kurun waktu Februari-Mei 2012 seperti pada Tabel 2, menunjukkan sebanyak 61 jenis burung dapat dijumpai di kawasan Kali Lamong dan terbagi ke dalam 27 famili. Dari jumlah tersebut sebanyak 30 jenis merupakan jenis burung air dan 31 jenis sisanya merupakan jenis non-burung air. Satu dari 61 jenis tersebut merupakan jenis raptor, yaitu Haliastur indus (Elang Bondol). Sementara delapan dari 61 jenis termasuk sebagai spesies burung migran, yaitu Todirhampus sanctus (Cekakak Suci), Hirundo rustica (Layang-layang Api), Calidris subminuta (Kedidi Jari Panjang), Calidris ruficollis (Kedidi Leher Merah), Actitis hypoleucos (Trinil Pantai), Tringa glareola (Trinil Semak), Numenius phaeopus (Gajahan Pengala), dan Numenius madagascariensis (Gajahan Timur).

Dua dari 61 jenis tersebut merupakan jenis endemik Jawa, yaitu Centropus nigrorufus (Bubut Jawa) dan Charadrius javanicus (Cerek Jawa). Hasil inventarisasi juga menunjukkan sebanyak empat dari 61 jenis tersebut masuk kedalam daftar IUCN Red Lists Threatened. Jenis tersebut adalah Charadrius javanicus (Cerek Jawa) berstatus Near Threatened, Mycteria cinerea (Bangau Bluwok) berstatus Vulnerable, Centropus nigrorufus (Bubut Jawa) berstatus Vulnerable, dan Numenius madagascariensis (Gajahan Timur) berstatus Vulnerable.

Selama sembilan kali waktu penelitian, terdapat 10 jenis burung yang selalu dijumpai. Dari kesepuluh jenis tersebut, tujuh di antaranya memiliki ketergantungan yang besar dengan kawasan perairan sebagai nesting sites, feeding sites, dan resting sites. Jenis tersebut adalah Todirhampus chloris (Cekakak Sungai), Alcedo coerulescens (Raja Udang Biru), Ardeola speciosa (Blekok Sawah), Butorides striatus (Kokoan Laut), Nycticorax nycticorax (Kowak Malam Kelabu), Casmerodius albus (Kuntul Besar), Egretta garzetta (Kuntul Kecil).

Kemudian Tiga jenis sisanya, Streptopelia chinensis (Tekukur Biasa), Hirundo tahitica (Layang-layang Batu), 
A

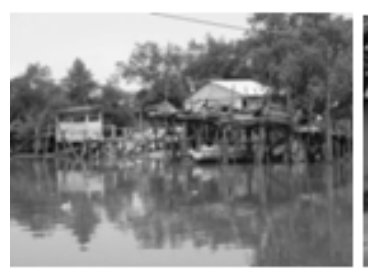

E

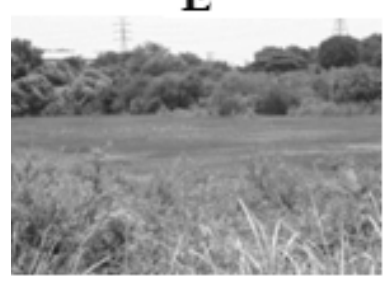

I

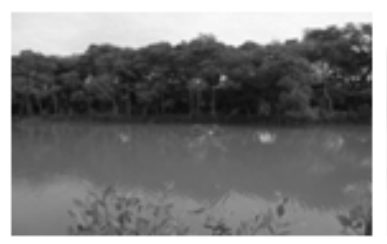

B

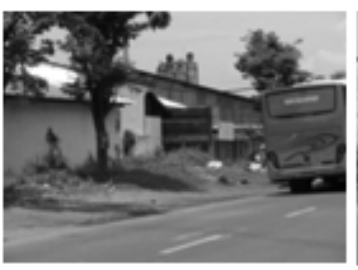

F

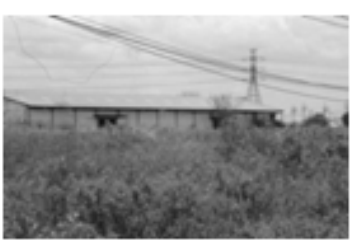

J

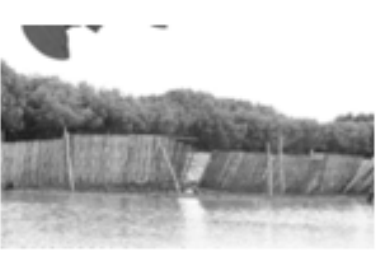

C

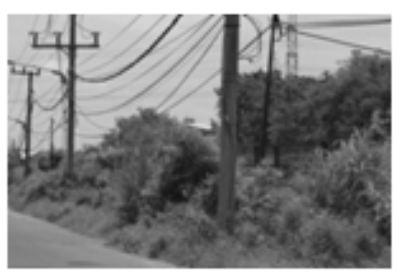

G

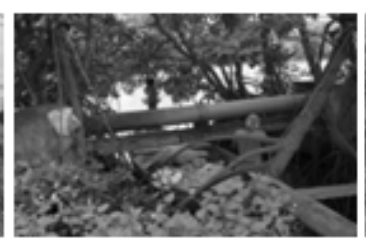

K

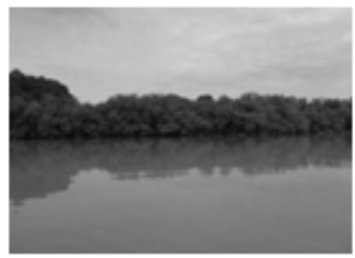

D

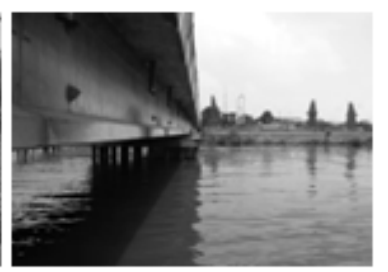

H

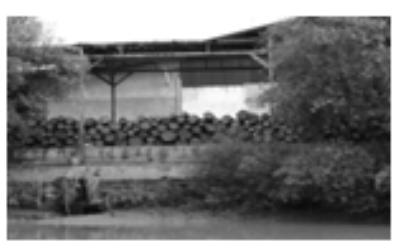

L

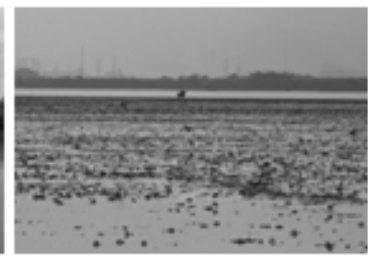

Gambar 2. Potret lokasi penelitian, (A) Stasiun I, (B) Stasiun II, (C) Stasiun III, (D) Stasiun IV, (E) Stasiun V, (F) Stasiun VI, (G) Stasiun VII, (H) Stasiun VIII, (I) Stasiun IX, (J) Stasiun X, (K) Stasiun XI, (L) Stasiun XII.

Tabel 2. Jenis Burung di Kawasan Muara Kali Lamong Beserta Status Perlindungan dan Migrasinya

\begin{tabular}{|c|c|c|c|c|}
\hline \multirow{2}{*}{ Famili } & \multicolumn{2}{|c|}{ Spesies Burung } & \multirow{2}{*}{ Status Perlindungan } & \multirow{2}{*}{$\begin{array}{l}\text { Status } \\
\text { Migras }\end{array}$} \\
\hline & Nama Latin & Nama Indonesia & & \\
\hline Accipitridae & Haliastur indus & Elang Bondol & Least Concern, IUCN 2009 & NM \\
\hline \multirow[t]{3}{*}{ Alcedinidae } & Todirhampus chloris & Cekakak Sungai & Least Concern, IUCN 2009 & NM \\
\hline & Todirhampus sanctus & Cekakak Suci & Least Concern, IUCN 2009 & M \\
\hline & Alcedo coerulescens & Raja Udang Biru & Least Concern, IUCN 2009 & NM \\
\hline Anatidae & Anas gibberifrons & Itik Benjut & Least Concern, IUCN 2009 & NM \\
\hline \multirow[t]{2}{*}{ Apodidae } & Apus affinis & Kapinis Rumah & Least Concern, IUCN 2009 & NM \\
\hline & Collocalia esculenta & Walet Sapi & Least Concern, IUCN 2009 & NM \\
\hline \multirow[t]{9}{*}{ Ardeidae } & Ardeola speciosa & Blekok Sawah & Least Concern, IUCN 2009 & NM \\
\hline & Ardea purpurea & Cangak Merah & Least Concern, IUCN 2009 & NM \\
\hline & Butorides striatus & Kokokan Laut & Least Concern, IUCN 2009 & NM \\
\hline & Nycticorax nycticorax & Kowak Malam Kelabu & Least Concern, IUCN 2009 & NM \\
\hline & Casmerodius albus & Kuntul Besar & Least Concern, IUCN 2009 & NM \\
\hline & Egretta garzetta & Kuntul Kecil & Least Concern, IUCN 2009 & NM \\
\hline & Bubulcus ibis & Kuntul Kerbau & Least Concern, IUCN 2009 & NM \\
\hline & Mesophyx intermedia & Kuntul Perak & Least Concern, IUCN 2009 & NM \\
\hline & Ixobrychus sinensis & Bambangan Kuning & Least Concern, IUCN 2009 & NM \\
\hline Artamidae & Artamus leucorhyncus & Kekep Babi & Least Concern, IUCN 2009 & NM \\
\hline Campephagidae & Lalage nigra & Kapasan Kemiri & Least Concern, IUCN 2009 & NM \\
\hline
\end{tabular}


Lanjutan Tabel 2

\begin{tabular}{|c|c|c|c|c|}
\hline \multirow{2}{*}{ Famili } & \multicolumn{2}{|c|}{ Spesies Burung } & \multirow{2}{*}{ Status Perlindungan } & \multirow{2}{*}{$\begin{array}{c}\text { Status } \\
\text { Migrasi }\end{array}$} \\
\hline & Nama Latin & Nama Indonesia & & \\
\hline \multirow[t]{3}{*}{ Charadriidae } & Charadrius javanicus & Cerek Jawa & Near Threatened, IUCN 2009 & NM \\
\hline & Charadrius dubius & Cerek Kalung Kecil & Least Concern, IUCN 2009 & NM \\
\hline & Charadrius alexandrinus & Cerek Tilil & Least Concern, IUCN 2009 & NM \\
\hline Chloropseidae & Aegithina tiphia & Cipoh Kacat & Least Concern, IUCN 2009 & NM \\
\hline Ciconiidae & Mycteria cinerea & Bangau Bluwok & Vulnerable, IUCN 2009 & NM \\
\hline Columbidae & Streptopelia chinensis & Tekukur Biasa & Least Concern, IUCN 2009 & NM \\
\hline Corvidae & Corvus enca & Gagak Hutan & Least Concern, IUCN 2009 & NM \\
\hline \multirow[t]{2}{*}{ Cuculidae } & Centropus nigrorufus & Bubut Jawa & Vulnerable, IUCN 2009 & NM \\
\hline & Cacomantis merulinus & Wiwik Kelabu & Least Concern, IUCN 2009 & NM \\
\hline Dicaeidae & Dicaeum trochileum & Cabai Jawa & Least Concern, IUCN 2009 & NM \\
\hline \multirow[t]{2}{*}{ Hirundinidae } & Hirundo rustica & Layang-layang Api & Least Concern, IUCN 2009 & $\mathrm{M}$ \\
\hline & Hirundo tahitica & Layang-layang Batu & Least Concern, IUCN 2009 & NM \\
\hline Meropidae & Merops phillipinus & Kirik-kirik Laut & Least Concern, IUCN 2009 & NM \\
\hline Muscicapidae & Rhipidura javanica & Kipasan Belang & Least Concern, IUCN 2009 & NM \\
\hline Nectariniidae & Cyniris jugularis & Burung Madu Sriganti & Least Concern, IUCN 2009 & NM \\
\hline Phalacrocoracidae & Phalacrocorax sulcirostris & Pecuk Padi Hitam & Least Concern, IUCN 2009 & NM \\
\hline Picidae & Dendrocopus macei & Caladi Tilik & Least Concern, IUCN 2009 & NM \\
\hline \multirow[t]{4}{*}{ Ploceidae } & Lonchura maja & Bondol Haji & Least Concern, IUCN 2009 & NM \\
\hline & Lonchura punctulata & Bondol Peking & Least Concern, IUCN 2009 & NM \\
\hline & Lonchura leucogastroides & Bondol Jawa & Least Concern, IUCN 2009 & NM \\
\hline & Passer montanus & Gereja Erasia & Least Concern, IUCN 2009 & NM \\
\hline \multirow[t]{2}{*}{ Pycnonotidae } & Pycnonotus aurigaster & Cucak Kutilang & Least Concern, IUCN 2009 & NM \\
\hline & Pycnonotus goiavier & Merbah Cerukcuk & Least Concern, IUCN 2009 & NM \\
\hline \multirow[t]{2}{*}{ Rallidae } & Amaurornis phoenicurus & Kareo Padi & Least Concern, IUCN 2009 & NM \\
\hline & Gallinula chloropus & Mandar Batu & Least Concern, IUCN 2009 & NM \\
\hline \multirow[t]{7}{*}{ Scolopacidae } & Numenius phaeopus & Gajahan Pengala & Least Concern, IUCN 2009 & $\mathrm{M}$ \\
\hline & Numenius madagascariensis & Gajahan Timur & Vulnerable, IUCN 2009 & $\mathrm{M}$ \\
\hline & Calidris subminuta & Kedidi Jari Panjang & Least Concern, IUCN 2009 & $\mathrm{M}$ \\
\hline & Calidris ruficollis & Kedidi Leher Merah & Least Concern, IUCN 2009 & $\mathrm{M}$ \\
\hline & Actitis hypoleucos & Trinil Pantai & Least Concern, IUCN 2009 & $\mathrm{M}$ \\
\hline & Tringa glareola & Trinil Semak & Least Concern, IUCN 2009 & $\mathrm{M}$ \\
\hline & Himantophus leucocephalus & Gagang Bayang Timur & Least Concern, IUCN 2009 & NM \\
\hline \multirow[t]{4}{*}{ Silviidae } & Cisticola juncidis & Cici Padi & Least Concern, IUCN 2009 & NM \\
\hline & Prinia inornata & Perenjak Padi & Least Concern, IUCN 2009 & NM \\
\hline & Prinia flaviventris & Perenjak Rawa & Least Concern, IUCN 2009 & NM \\
\hline & Gerygone sulphurea & Remetuk Laut & Least Concern, IUCN 2009 & NM \\
\hline \multirow[t]{6}{*}{ Sternidae } & Sterna hirundo & Dara Laut Biasa & Least Concern, IUCN 2009 & NM \\
\hline & Sterna albifrons & Dara Laut Kecil & Least Concern, IUCN 2009 & NM \\
\hline & Chlidonias hybridus & Dara Laut Kumis & Least Concern, IUCN 2010 & NM \\
\hline & Chlidonias leucopterus & Dara Laut Sayap Putih & Least Concern, IUCN 2009 & NM \\
\hline & Gelochelidon nilotica & Dara Laut Tiram & Least Concern, IUCN 2009 & NM \\
\hline & Sterna sumatrana & Dara Laut Tengkuk Hitam & Least Concern, IUCN 2009 & NM \\
\hline Zosteropidae & Zosterops palpebrosus & Kacamata Biasa & Least Concern, IUCN 2009 & NM \\
\hline
\end{tabular}

Keterangan: Penamaan ilmiah spesies burung merujuk pada MacKinnon, dkk (2010). M = Migran, NM = Non-Migran. 
dan Passer montanus (Gereja Erasia) bukan merupakan jenis burung air, dan bersifat kosmopolit yang memiliki persebaran sangat luas serta memiliki daya adaptasi tinggi terhadap berbagai tipe habitat. MacKinnon, dkk. (2010) mengatakan ketiga jenis tersebut dapat berasosiasi dekat dengan manusia. Hidup berkelompok di sekitar rumah, pergudangan, dan lain-lain. Mereka mencari makan di berbagai lahan terbuka yang menghasilkan biji-biji kecil, kecuali Hirundo tahitica (Layang-layang Batu) yang memangsa serangga-serangga kecil.

Peterson (1980) dalam Rusmendro, dkk. (2009), menyatakan bahwa suatu komunitas dapat dibagi ke dalam bagian yang lebih kecil dari suatu asosiasi tumbuhtumbuhan seperti pucuk, tajuk, dan batang. Penyebaran burung erat hubungannya dengan ketersediaan makanan atau dengan kata lain, burung tersebut memerlukan tempat khusus untuk hidupnya.

Gambar 3 menjelaskan bahwa kawasan pertambakan di sekitar Kali Lamong memiliki nilai keanekaragaman yang paling tinggi, yaitu 3,19. Diikuti oleh lahan kosong $(2,52)$, perindustrian $(2,39)$, hutan mangrove $(2,06)$, dan permukiman $(1,67)$. Tingginya angka keanekaragaman di kawasan pertambakan dapat disebabkan kawasan ini menyimpan banyak persediaan makanan bagi hampir semua jenis burung, terutama burung air.

Menurut Romimohtarto dan Juwana (2001), indeks keanekaragaman (diversity index) digunakan untuk mengetahui keanekaragaman hayati biota yang diteliti. Apabila nilai indeks ini semakin tinggi, maka komunitas biota semakin beragam dan tidak di dominasi oleh satu atau dua takson saja.

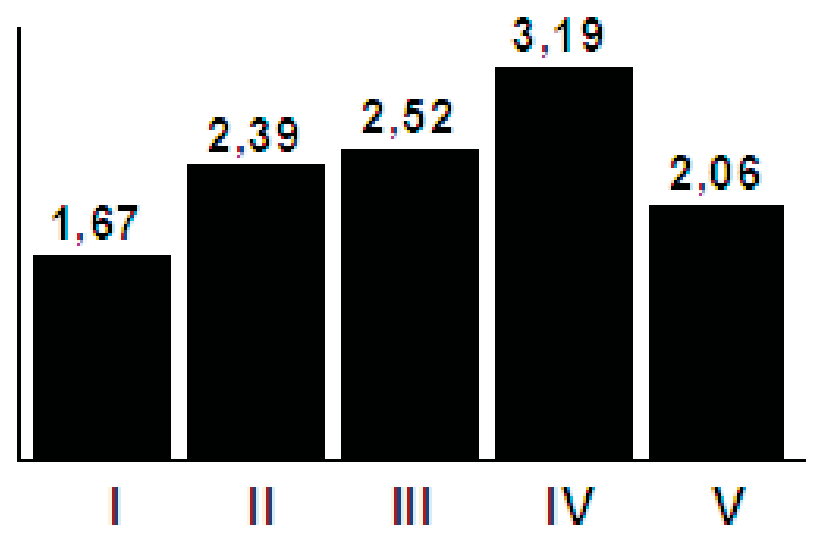

Gambar 3. Grafik indeks keanekaragaman Shannon-Wiener di kawasan muara Kali Lamong (Oktober 2011 - Mei 2012). I: permukiman; II: perindustrian; III: lahan kosong; IV: pertambakan; $\mathrm{V}$ : hutan mangrove.

\section{PEMBAHASAN}

Melalui pendataan terhadap keanekaragaman jenis burung, dapat diidentifikasi bila kondisi habitat kurang baik untuk mendukung kehidupan burung seperti kurangnya sumber pakan dan atau faktor lain (luas area dan iklim), maka dapat mempengaruhi keberadaan jenis burung itu sendiri (Hernowo, dkk., 1988).

Hasil pengamatan di kawasan muara Kali Lamong menunjukkan bahwa pada kelima tipe pemanfaatan lahan yang diamati terdapat perbedaan tidak hanya jumlah jenis burungnya saja, melainkan juga ada perbedaan pada jumlah jenis burung berdasar tipe distribusinya (kosmopolitan-endemik), habitatnya, statusnya, frekuensi perjumpaannya yang dapat ditagsirkan sebagai kepadatan relatifnya, dan juga tingkat keanekaragamannya sebagaimana disajikan pada Tabel 3. Burung-burung di kawasan ini juga memanfaatkan keberadaan mangrove di kawasan tambak untuk bersarang dan beristirahat. Widodo, (2009), memberikan pernyataan bahwa habitat yang kondisinya baik dan jauh dari gangguan manusia serta di dalamnya mengandung bermacam-macam sumber pakan, memungkinkan memiliki jenis burung yang banyak.

Nilai 2,52 pada kawasan lahan kosong menjelaskan bahwa kawasan tersebut menyimpan sumber pakan yang banyak disukai burung-burung. Semak belukar yang terdapat di kawasan ini dapat menjadi salah satu faktor yang membuat burung-burung tersebut tertarik untuk singgah. Semak belukar yang rapat merupakan tempat berlindung yang baik bagi burung terutama yang bertubuh kecil terhadap serangan angin kencang, udara, dingin, dan predator yang lebih besar (Rusmendro, dkk., 2009).

Kawasan industri seperti terlihat dalam Gambar 3 meskipun memiliki nilai indeks keanekaragaman hanya 2,39, namun masih memiliki keanekaragaman yang cukup tinggi. Hal ini bisa disebabkan susahnya akses masuk ke kawasan industri, membuat burung-burung di lokasi tersebut seolah 'tak terjamah' oleh kegiatan manusia secara langsung, sehingga mereka dapat dengan bebas beraktivitas. Padahal kawasan ini terus berkembang secara dinamis dan burung-burung yang terdapat di lokasi ini tengah terancam proses pengembangan kawasan yang begitu cepat. Pembangunan gedung, permukaan yang tidak dapat ditembus air, dan berbagai macam polusi di kota lebih jauh dapat mempengaruhi lingkungan termasuk pada cuaca, juga terhadap komposisi jenis terutama fauna burung akibat kebisingan dan cahaya (Hardes dan Spellberg, 1992 dalam Anonim, 1999). 
Tabel 3. Keanekaragaman Jenis Burung di Setiap Tipe Pemanfaatan Lahan

\begin{tabular}{|c|c|c|c|c|c|}
\hline \multirow[b]{2}{*}{ Atribut } & \multicolumn{5}{|c|}{ Tipe Lahan } \\
\hline & Permukiman & Perindustrian & $\begin{array}{c}\text { Lahan } \\
\text { Kosong }\end{array}$ & Pertambakan & $\begin{array}{c}\text { Hutan } \\
\text { Mangrove }\end{array}$ \\
\hline Jenis Burung & 22 & 17 & 24 & 52 & 31 \\
\hline Jenis Burung Air & 5 & 7 & 6 & 24 & 22 \\
\hline Jenis Burung Endemik & 1 & & & 1 & 1 \\
\hline Jenis Burung Kosmopolitan & 8 & 7 & 9 & 8 & 4 \\
\hline Jenis Burung Yang Dilindungi & 1 & & & 1 & 3 \\
\hline Jenis Burung Yang Sering Terlihat & 4 & & 2 & 4 & 7 \\
\hline Jumlah Jenis Burung Migran & 2 & 1 & 1 & 7 & 7 \\
\hline Jenis Burung Raptor & & & 1 & & 1 \\
\hline Indeks Keanekaragaman & 1,67 & 2,39 & 2,52 & 3,19 & 2,06 \\
\hline Jenis Burung Yang Dominan & 3 & 5 & 6 & 4 & 5 \\
\hline
\end{tabular}

Selanjutnya, untuk kawasan hutan mangrove yang hanya bernilai 2,06 menjelaskan bahwa melalui kegiatan pengamatan ini diketahui burung-burung di kawasan hutan mangrove (Pulau Galang) sebagai jenis yang memanfaatkan lokasi tersebut untuk tempat beristirahat. Terkecuali pada saat kondisi air laut surut, burung-burung terlihat ramai berada di gosongan lumpur untuk mencari makan. Selebihnya pada saat air laut pasang, burung-burung (terutama burung air), lebih sering teramati tengah berjemur saja bersama koloninya di tengah Pulau Galang.

Kawasan permukiman menjadi kawasan dengan nilai keanekaragaman paling rendah, yaitu 1,67 yang berarti dalam skala sedang. Menurut Alikodra, (1990) dalam Rusmendro, dkk. (2009), faktor yang mempengaruhi nilai H' (keanekaragaman) adalah kondisi lingkungan, jumlah jenis, dan sebaran individu pada masing-masing jenis. Komunitas yang memiliki nilai indeks keanekaragaman tinggi memiliki hubungan antar komponen dalam komunitas yang kompleks. Namun, bila keadaan sebaliknya, keanekaragaman jenis komunitas sedang mengalami tekanan (Rusmendro, dkk., 2009).

Indeks keanekaragaman membuktikan bahwa kekayaan hayati dalam suatu kawasan didukung secara penuh oleh kondisi ekologis di sekelilingnya. Mulai dari aktivitas makhluk hidup lain yang hidup berdampingan, keberadaan predator, ketersediaan pakan, hingga ketersediaan tempat tinggal yang aman dan nyaman untuk burung tersebut hingga dapat berkembang biak. Melalui Gambar 3, jelas bahwa keragaman spesies burung merupakan suatu refleksi dari bermacam-macam habitat dan kondisi iklim yang mampu mendukungnya (Sajithiran, dkk., 2004).
Hasil pengamatan menunjukkan bahwa terdapat nilai keanekaragaman yang berbeda antar tipe pemanfaatan lahan di kawasan muara Kali Lamong sebagaimana disajikan pada Tabel 3.

\section{DAFTAR PUSTAKA}

Anonim, 1999. Studi Keanekaragaman dan Kelimpahan Burung Pada Beberapa Daerah Industri di Kabupaten Gresik. Laporan Penelitian. Kelompok Studi Burung Peksia. Himpunan Mahasiswa Biologi Senat Mahasiswa FMIPA Universitas Airlangga. Surabaya.

Arisandi, P. 1999. Studi Struktur Komunitas dan Keanekaragaman Mangrove Berdasarkan Tipe Perubahan Garis Pantai di Pantai Utara Jawa Timur. Skripsi. Jurursan Biologi. Universitas Airlangga. Surabaya.

Bapeprov Jatim, 2010. Menyoal Pelabuhan Teluk Lamong. http://www.bappeda.jatimprov.go.id. diakses tanggal 12 September 2011.

Bushan, B., G. Fry, A. Hibi, T. Mundkur, D.M., Prawiladilaga, K. Sonobe, dan S. Usui, 1993. A Field Guide To The Waterbirds of Asia. Wild Bird Society of Japan. Jepang.

Carlton, C. 2004. Bird Survey Methods. National Parks Association. Australia.

Hernowo, J.B., Wibowo, C., Santoso, N., dan Kusmaryadi, N. 1988. Ecological Study of Tinjil Island With Special Emphasize on Long Tailed Macaques, Birds, and Vegetation. Research Report. Departement of Forest Resources Conservation. Faculty of Forestry. IPB. Bogor.

Hostetler, M.E., dan M.B. Main, 2011. Florida Monitoring Program: Point Count Method to Survey Birds. Wildlife Ecology and Conservation Departement. Institute of Food and Agricultural Sciences. University of Florida. Florida.

MacKinnon, J., K. Phillips, dan B. van Balen, 2010. Burungburung di Sumatera. Jawa. Bali. dan Kalimantan. LIPIBurung Indonesia. Bogor. 
Romimohtarto, K., dan S. Juwana, 2001. Biologi Laut: Ilmu Pengetahuan tentang Biota Laut. Penerbit Djambatan. Jakarta.

Rusmendro, H., Ruskomalasari, A. Khadafi, H.B., Prayoga, dan L. Apriyanti, 2009. Keberadaan Jenis Burung Pada Lima Stasiun Pengamatan di Sepanjang Daerah Aliran Sungai (DAS) Ciliwung. Depok-Jakarta. Jurnal Penelitian Universitas Nasional VIS VITALIS. 2(2): 50-64.

Sajithiran, T.M., Jamdhan, S.W., dan Santiapillani, C. 2004. A Comparative Study of The Diversity of Birds in Three Reservoirs in Vavuniya, Srilanka. Srilanka. Tiger Paper. 31(4): 27-32.

Shahnaz, J, P. Jepson, dan Rudyanto, 1995. Burung-burung Terancam Punah di Indonesia. Departemen KehutananBirdlife International Indonesia Programme. Bogor.
Soegianto, A. 1994. Ekologi Kuantitatif. Metode Analisis Populasi Komunitas. Usaha Nasional. Surabaya.

Sulistyaningsih, B. 2009. Prediksi Laju Sedimentasi di Muara kali Lamong Menggunakan Model Matematis Aliran dan Angkutan Sedimen. Tesis. Institut Teknologi Sepuluh November. Surabaya.

Widodo, W. 2009. Komparasi Keragaman Jenis Burung-Burung di Taman Nasional Baluran dan Alas Purwo Pada Beberapa Tipe Habitat. Jurnal Berkala Penelitian Hayati. 14(2): $113-124$

Note:

This report is part of a bachelor thesis of the first author under the supervision of the second and third author. 